\title{
Holocene Climate and Climate Variability of the Northern Gulf of Mexico and Adjacent Northern Gulf Coast: A Review
}

\author{
Richard Z. Poore* \\ U.S. Geological Survey, Florida Integrated Science Center, St. Petersburg, Florida, USA
}

\begin{abstract}
Marine records from the northern Gulf of Mexico indicate that significant multidecadal- and century-scale variability was common during the Holocene. Mean annual sea-surface temperature (SST) during the last 1,400 years may have varied by $3^{\circ} \mathrm{C}$, and excursions to cold SST coincide with reductions in solar output. Broad trends in Holocene terrestrial climate and environmental change along the eastern portion of the northern Gulf Coast are evident from existing pollen records, but the high-frequency details of climate variability are not well known. Continuous and well-dated records of climate change and climate variability in the western portion of the northern Gulf Coast are essentially lacking.

Information on Holocene floods, droughts, and storm frequency along the northern Gulf Coast is limited. Records of floods may be preserved in continental shelf sediments, but establishing continuity and chronologies for sedimentary sequences on the shelf presents challenges due to sediment remobilization and redeposition during storms. Studies of past storm deposits in coastal lakes and marshes show promise for constructing records of past storm frequency. A recent summary of sea-level history of the northern Gulf Coast indicates sea level was higher than modern sea level several times during the last few thousand years.
\end{abstract}

\section{INTRODUCTION}

The coastal region of the northern Gulf of Mexico (GOM) is a dynamic environment that contains both renewable and nonrenewable resources of great importance to the Nation. Northern Gulf Coast ecosystems support most of the Nation's wintering waterfowl and account for about one third of the fisheries production in the lower 48 states [1]. The lower Mississippi River is the site of the largest port activity by tonnage in the World. Further, refineries along the northern Gulf Coast produce about $\$ 30$ billion worth of petroleum products per year, and approximately $20 \%$ of U.S. crude oil and $33 \%$ of U.S. natural gas flows through the region [2].

Rapid growth of coastal communities has resulted in an ever-increasing human population and economic infrastructure. Since 1900, population density in most coastal counties along the northern GOM has increased substantially. Some coastal counties in Texas, Louisiana, Alabama, and Florida have experienced increases of thousands of people per square mile (Fig. 1).

The northern GOM coastal region is vulnerable to a variety of natural hazards. Major storms are one notable example. A number of major hurricanes have made landfall in the northern GOM since 1900 (Fig. 2). Major droughts are another example. Prolonged drought conditions in the southwestern United States in the 1950s and 1960s resulted in very dry conditions for a number of years along the northern Gulf Coast.

*Address correspondence to this author at the Florida Integrated Science Center, St. Petersburg, Florida, USA; Tel: 727-803-8747, Ext. 3131;

E-mail: rpoore@usgs.gov
Prior to the European colonization in the last few hundred years, changes in the physical system, including sea level, sediment supply, storm frequency, temperature and precipitation extremes, and the resulting impact on ecosystems, were driven by natural variability in Earth's climate system and tectonic forces that operate on time scales ranging from tens of thousands of years to several years duration. During the last few hundred years, human activities have become an increasingly important influence on the environment of the northern Gulf Coast. For example, construction of levees and dams along rivers has altered the supply of freshwater and sediment to coastal systems, and increasing concentrations of atmospheric greenhouse gases are leading to climate warming and possible changes in the hydrologic cycle [3]. Thus, changes and variability in the region today are driven by a complex combination of natural and anthropogenic forcing. This report reviews information regarding the Holocene climate and its variability in the northern GOM and adjacent coastal region, and suggests areas for additional research.

\section{Current Climate Setting}

The GOM is a semi-enclosed basin at the northwestern edge of the tropical Atlantic Ocean. The GOM is closely linked to the Caribbean and tropical Atlantic via the Loop Current, which is a surface-ocean current that transports warm waters from the Caribbean Sea through the Yucatan Straits and into the GOM, before exiting through the Florida Straits to be incorporated into the Gulf Stream (Fig. 3). Seasurface temperature (SST) and atmospheric circulation in the GOM region undergo annual changes linked to seasonal migration of the Intertropical Convergence Zone (ITCZ) (Fig. 3). This variation strongly influences the climate of the northern Gulf Coast as well as large areas of North America. 


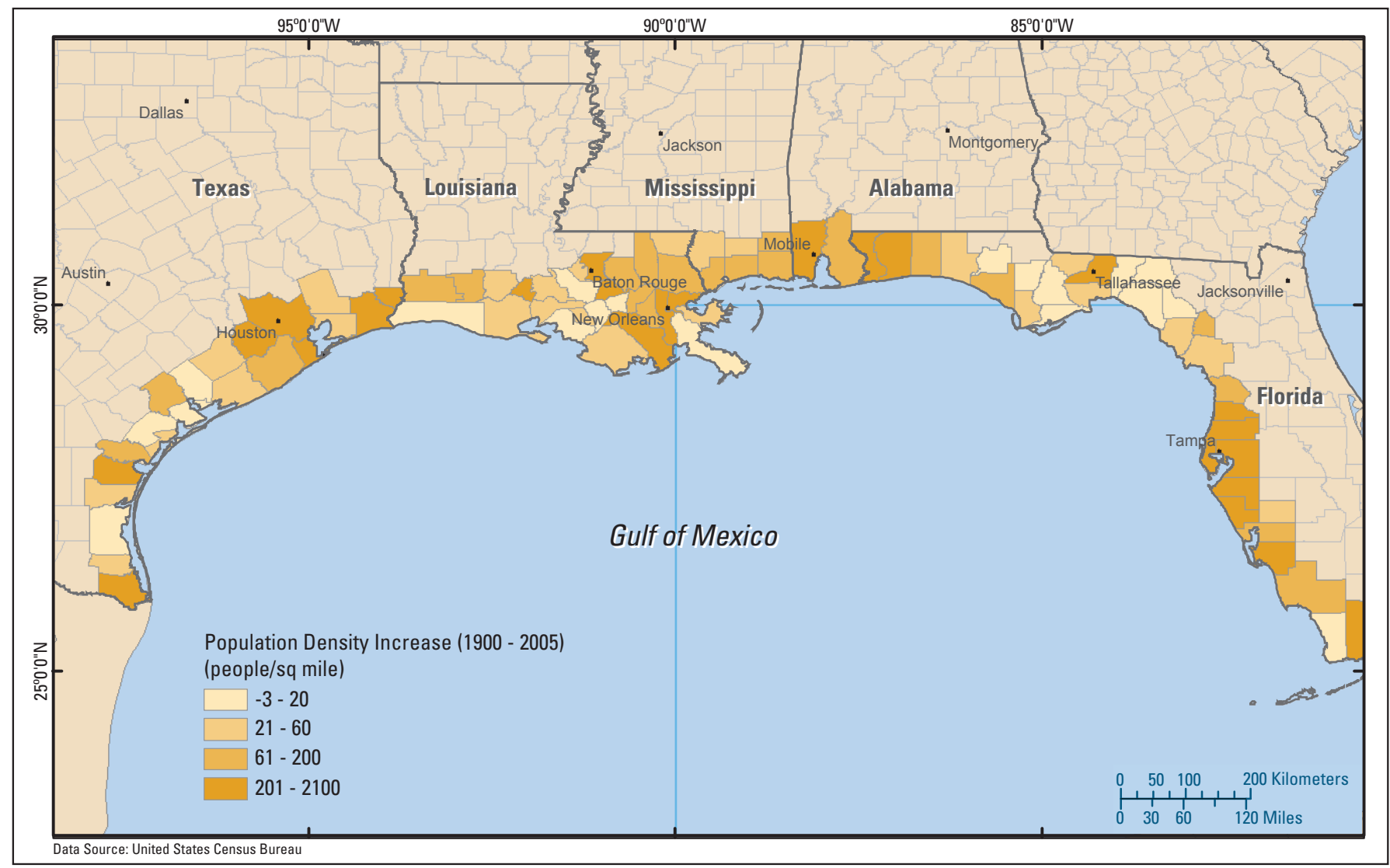

Fig. (1). Population density increase from 1900 to present within counties along the Gulf of Mexico coastline (from Brock et al. (in press) [58]).

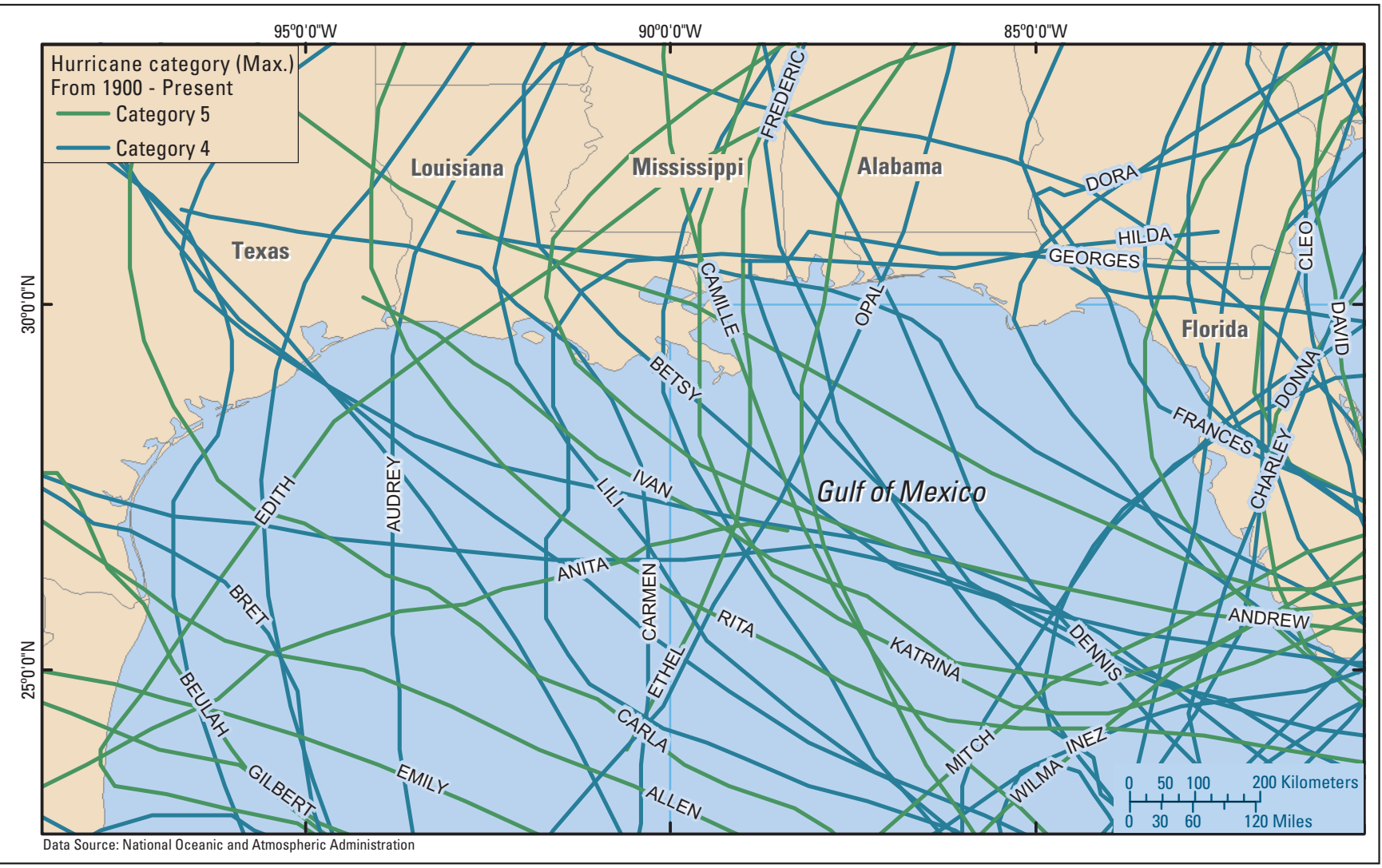

Fig. (2). Tracks of category 4 and category 5 hurricanes that have entered the Gulf of Mexico since 1900. Data are from NOAA Coastal Services Center [59]. 


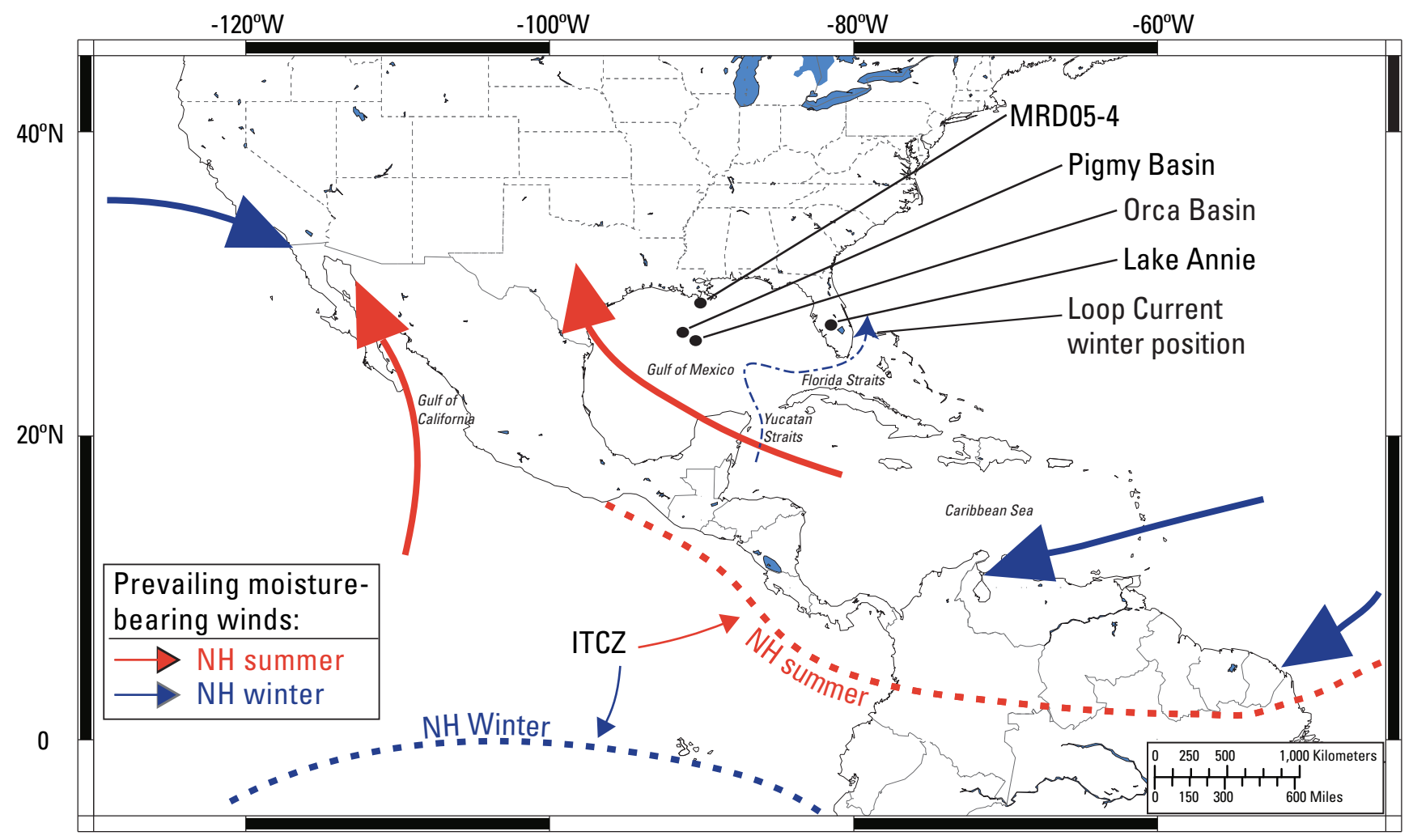

Fig. (3). Map showing location of selected localities discussed in text. Generalized path of prevailing moisture bearing winds and position of the Intertropical Convergence Zone (ITCZ) for Northern Hemisphere winter and summer are shown by bold arrows and dashed lines. Bold dotted line shows approximate northern limit of monsoon boundary where more than $50 \%$ of annual precipitation occurs during the warm season (adapted from Poore et al. (2004) [26]).

During the Northern Hemisphere (NH) summer (Fig. 3), the ITCZ is north of the Equator. Southeasterly surface winds across the Caribbean Sea and GOM, as well as southerly winds across the Gulf of California, result in monsoonal rainfall in Mexico and the southwestern United States (the American monsoon). During summer, GOM SSTs exceed $28^{\circ} \mathrm{C}$ and are part of the Western Hemisphere Warm Pool (WHWP) [4]. The WHWP, which extends from the eastern North Pacific Ocean through the GOM and Caribbean and into the tropical Atlantic, is the dominant heat source for the Western Hemisphere extratropics during the summer [4]. The GOM is the primary moisture source for the northern Gulf Coast and eastern North America [5].

During the Northern Hemisphere winter, the ITCZ moves south to a position near the Equator (Fig. 3). Prevailing winds shift from southeasterly to northeasterly across the Caribbean and GOM, and monsoon circulation ceases. During boreal winter, the Loop Current generally does not penetrate into the western or northern GOM. Surface waters in the northern GOM cool, and precipitation along the northern Gulf Coast generally declines due to the lower SST and decreased convection. Warm waters from the Caribbean are usually restricted to the southeastern GOM due to the flow of the Loop Current from the Yucatan Straits to the Florida Straits. However, the penetration of the Loop Current into the northern GOM varies annually, and anticyclonic eddies that break off the Loop Current at irregular intervals can bring warm waters to the northern and central GOM during some winters [6]. Seasonal changes in SST are about $8^{\circ} \mathrm{C}$ in the western and northern GOM (see Brunner 1982 [7], Fig. 1).

The climate along the northern Gulf Coast is influenced by the proximity of the waters of the Gulf of Mexico. Most of the northern Gulf Coast is humid subtropical and supports temperate evergreen-forest vegetation, but the southern tip of Florida is tropical [8]. Precipitation in the eastern part of the coastal region is highest in the summer and fall. Annual distribution of precipitation is more uniform in the central part of the Gulf Coast. In general, annual precipitation declines inland from the Gulf and from the central part of the Gulf Coast to the west. Coastal areas of far western Texas are semi-arid and support a live-oak forest [8].

The northern Gulf Coast is sensitive to several interdecadal to interannual natural oscillations or cycles in oceanatmosphere circulation. Two important cycles that influence conditions along the northern Gulf Coast are the El Niño Southern Oscillation (ENSO), and the Atlantic Multidecadal Oscillation (AMO).

ENSO involves changes in trade winds and the SST gradient across the equatorial Pacific Ocean. During normal conditions, strong easterly trade winds in the eastern equatorial Pacific blow warm surface waters to the west. Cool subsurface waters upwell off the coast of the Americas in the eastern Pacific. This results in a surface pool of very warm waters in the western Pacific (the western Pacific Warm 
Pool), and cool surface waters in the eastern Pacific off the coast of the Americas, creating a strong SST gradient between the eastern and western equatorial Pacific. During a warm phase in ENSO (or an El Niño), the trade winds diminish in strength, and the warm waters of the western Pacific move back toward the east, resulting in a warm SST off the coast of the Americas (see discussion in Philander (1996) [9]). El Niño events tend to occur every $3-7$ years. One effect of an El Niño event on the Gulf Coast is an increase in annual rainfall (e.g., Darby and Sondag (2003) [10]). The reduction in easterly trade winds during an El Niño event creates less favorable conditions for landfall of hurricanes along the Gulf Coast [11-13].

The AMO involves alternating intervals of persistent above average and below average SST in the North Atlantic Ocean [14], with a cycle of 60-80 years. Limited data indicate warm phases of the AMO correlate with an increased number of major hurricanes per decade in the Atlantic [12] (Fig. 4). The impact of these natural oscillations on specific areas of the northern Gulf Coast is complicated and in some cases the AMO phase can influence the effects of the ENSO phase [15].

\section{Holocene Climate Trends and Variability}

Most paleoceanographic studies in the Gulf of Mexico have used analyses of assemblages and shell chemistry of microfossils (primarily planktic foraminifers) in sediment cores to estimate variations in sea-surface temperature in the Gulf of Mexico. Malmgren and Kennett [16] used principal component analysis of foraminiferal-assemblage data from a series of cores in the western GOM to develop qualitative estimates of SST changes through the Holocene. Brunner [7] used the transfer function technique of Imbrie and Kipp [17] to estimate SSTs and salinities extending back through the last interglacial in several cores from the GOM. The sampling strategy of Brunner [7] was designed to establish the glacial-interglacial signal and includes only a few SST estimates for the Holocene. However, the sparse record indicates the warmest winter SST occurred during the mid-Holocene [7].

Kennett et al. [18] and Flower and Kennett [19, 20] determined the relative abundance of planktic foraminifers and $\delta^{18} \mathrm{O}$ of Globigerinoides ruber (white variety) at a sampling interval of about 250 to 300 years in cores from the Orca Basin on the Louisiana slope, south of the Mississippi River. The foraminifer assemblages show clear differences between older and younger parts of the Holocene. The warmest surface-water temperatures, as indicated by high relative abundances of Pulleniatina obliquiloculata and G. menardii [20], occurred at about $5 \mathrm{ka}$, which is consistent with the results of Brunner (1982) [7].

Poore et al. (in press) [21] summarized census data on foraminifer assemblages in several cores from the western

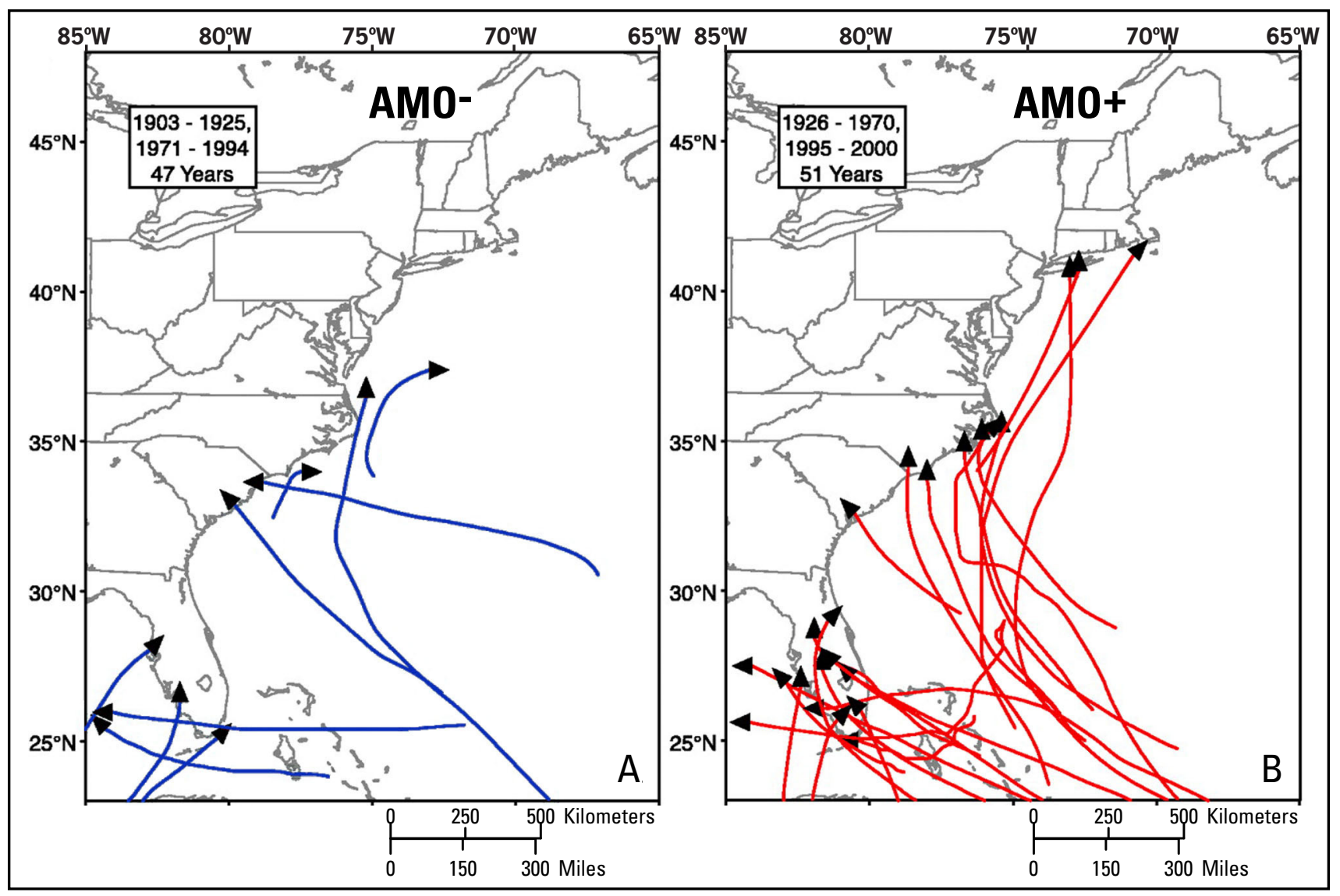

Fig. (4). Map showing landfalls of major (categories 3, 4, and 5) hurricanes on the east coast of the United States during intervals of time representing (A) cold, AMO- and (B) warm, AMO + phases of the Atlantic Multidecadal Oscillation (AMO) (from Goldenberg et al. (2001) [12]). 
and northern GOM, spanning most of the Holocene, and concluded that the relative abundance of the G. sacculifer in GOM foraminiferal assemblages is a reliable proxy for changes in the average position of the ITCZ. The census data confirm previous work, indicating that the average position of the ITCZ reached its northern extent in the mid-Holocene and has been migrating southward since about $5 \mathrm{ka}$ to the present [22]. The results are consistent with the interpretation that monsoonal precipitation in the southwestern U.S. was high in the middle part of the Holocene and has been decreasing since about 5 ka [23]. Higher-frequency (centuryscale) changes in the average position of the ITCZ and associated changes in the southwest monsoon appear to be related to changes in solar output. Inspection and statistical analyses of several Pleistocene and Holocene climate proxy records has revealed persistent century- to millennial-scale cyclicity, and some of these cycles are similar to concentrations of variance found in analyses of changes in the rate of ${ }^{14} \mathrm{C}$ production. Since variation in ${ }^{14} \mathrm{C}$ production is related to changes in solar output, the occurrence of similar cycles in climate proxy and ${ }^{14} \mathrm{C}$ production records provides evidence linking solar variability and multidecadal- to century-scale climate change. For example, a 208-yr cycle is prominent in the ${ }^{14} \mathrm{C}$ production record (e.g., Stuiver and Braziunas (1993) [24]), and cycles near 200 years are present in several climate proxy records from the Caribbean (e.g., Hodell et al. (2001) [25]) and GOM (e.g., Poore et al. (2004) [26]).

Detailed records of SST are available for the early part of the Holocene from the Orca Basin [27] and for the last $1.4 \mathrm{ka}$ from the nearby Pigmy Basin [28], both of which are located in the northern GOM (Fig. 3). Both studies measured $\mathrm{Mg} / \mathrm{Ca}$ in the planktic foraminifer G. ruber (white variety) to construct a record of mean annual SST. The Orca Basin time series extends from $10-7 \mathrm{ka}$ and shows a gradual warming of about $1.5^{\circ} \mathrm{C}$ from 10.5 to $7 \mathrm{ka}$, overprinted on centuryscale SST oscillations of several degrees Celsius [27]. Richey et al. (2007) [28] developed a highly resolved (i.e., sampling resolution about 12 years) mean annual SST record for the last $1.4 \mathrm{ka}$ years by measuring $\mathrm{Mg} / \mathrm{Ca}$ in $G$. ruber (white variety) in a core from the Pigmy Basin (Fig. 5). The Pigmy Basin record indicates mean annual SST varied by as much as $3^{\circ} \mathrm{C}$ over the last $1.4 \mathrm{ka}$. Intervals of coolest SST correspond with intervals known as the coldest periods of the Little Ice Age (LIA), and warm SST intervals between 1,000 and 1,400 years BP coincide with the oldest part of the Medieval Warm Period. The variability of SST observed in the Pigmy Basin record is consistent with estimates of SST cooling during the LIA from coral records in Puerto Rico and the Florida Straits [28]. Many of the excursions to cool SST in the Pigmy Basin record during the last $1 \mathrm{ka}$ coincide with intervals of lower sunspot activity or sunspot minima known from the historical record. These sunspot minima named Maunder, Sporer, Wolf, and Oort, represent intervals of lower solar output [29]. The correspondence of cool SST excursions with sunspot minima shown in Fig. (5) provides evidence for the Influence of solar output on climate variability. However, additional work is needed to clearly establish the direct link between variations in solar output and climate variability. Overall, the SST records from the Orca and Pigmy Basins, along with the foraminifer census data summarized by Poore et al. (in press) [21], indicate that sig-

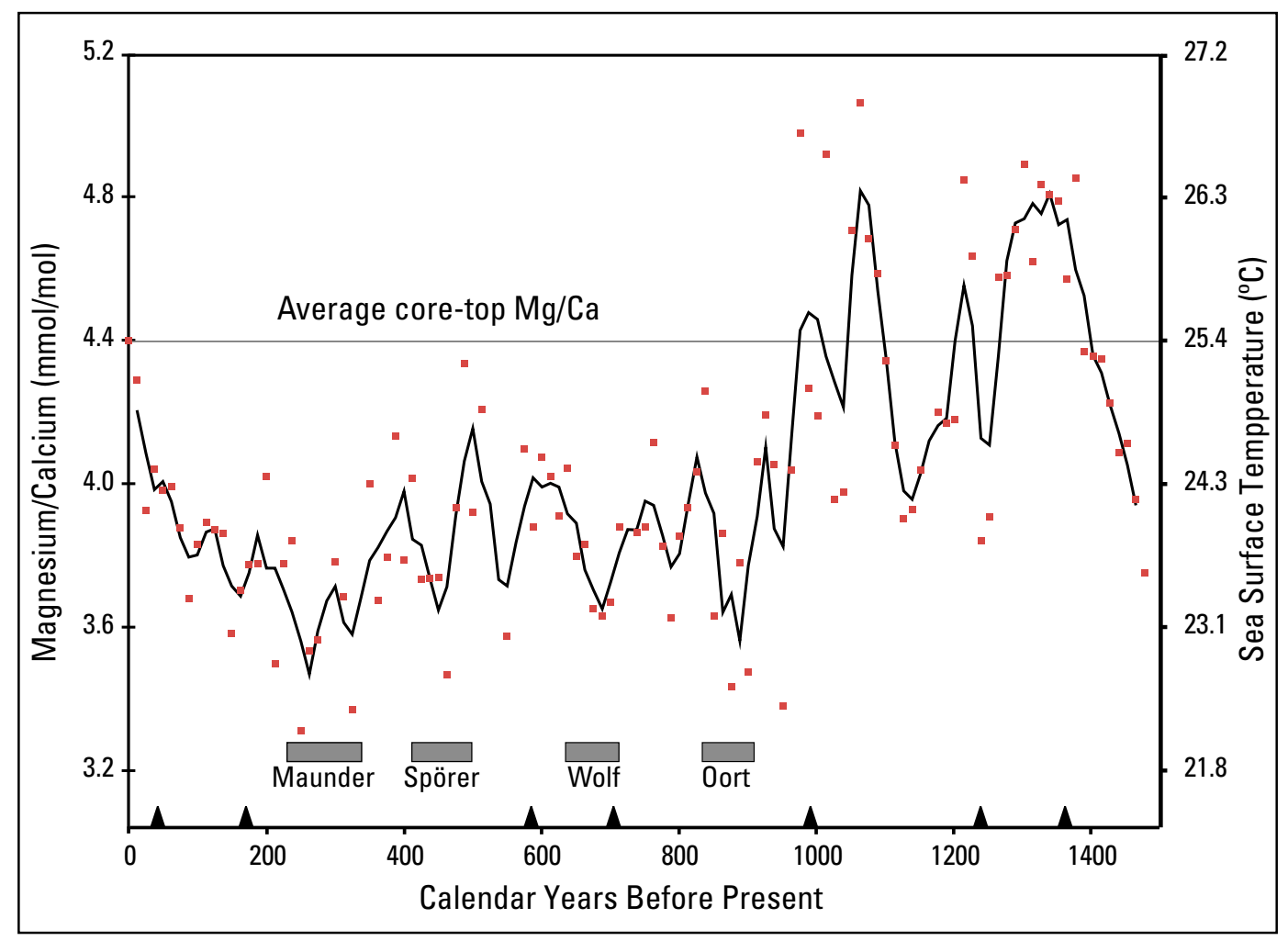

Fig. (5). Record of $\mathrm{Mg} / \mathrm{Ca}$ measured in Globigerinoides ruber (white variety) in sediment core from the Pigmy Basin. Sea surface temperature conversion of $\mathrm{Mg} / \mathrm{Ca}$ is shown on right axis. Red dots indicate individual $\mathrm{Mg} / \mathrm{Ca}$ in each sample and solid line is three-point running mean. Triangles on age scale show location of radiocarbon dates used to construct the age model for the record. Gray bars show age range of the Maunder, Sporer, Wolf and Oort sunspot minima (modified from Richey et al. (2007) [28]). 
nificant multidecadal- to century-scale climate variability is persistent throughout the Holocene in the GOM.

Information on terrestrial climate and climate variability of the northern Gulf Coast has been primarily derived from analyses of pollen assemblages in sediment cores recovered from a variety of environments. Records from lakes and large estuaries typically represent a regional climate signal. Pollen from marsh and other wetland deposits tend to represent more local conditions, but can be very sensitive to highfrequency changes [30]. Detailed quantitative estimates of climate and climate variability from the northern Gulf Coast are not common. Most published studies focus on describing general changes in vegetation types.

A number of well-dated Holocene records are available from lake deposits in Florida (see summary in Willard (2007) [30]). The primary signal in Florida Holocene pollen sequences is a change from oak-dominated forests in the early Holocene to pine-dominated forests in the late Holocene (Fig. 6). The change is well documented in long and well-dated pollen records from central Florida including Lake Annie [31] and Lake Tulane [32]. The increase in pine is interpreted to represent warmer winters and increased effective moisture in the later part of the Holocene compared to the early part of the Holocene (see discussion in Willard (2007) [30]). At the start of the Holocene (about $10 \mathrm{ka}$ ) sea level was around 30 meters below modern sea level and rose fairly rapidly to within about 5 meters of modern sea level at about $6 \mathrm{ka}$. The sands and carbonate rocks underlying central and southern Florida are very permeable and many modern lakes in central Florida were dry during the early deglacial because lower sea level resulted in a depressed water table [33]. Thus, in Florida, part of the increase in effective moisture in the later part of the Holocene could be related to increased elevation of the water table associated with rising sea level.

The mid-Holocene transition from oak-dominated to pine-dominated pollen assemblages at about $5 \mathrm{ka}$ observed in the Florida records, is also found in the Goshen Springs pollen record from southern Alabama [34]. Pine also dominates a pollen record extending back to about $4.7 \mathrm{ka}$, recovered from Lake Shelby on the barrier island off Mobile Bay, Alabama [35]. Thus, the pattern of vegetation change seen in the Florida records is representative of conditions across the eastern portion of the Gulf Coast.

Few well-dated and continuous Holocene climate records are available from the rest of the northern Gulf Coast. Large fossil meander scars considered to be mid-Holocene in age ( 7.5 to $4.0 \mathrm{ka}$ ) along the Sabine River in southwest Louisiana provide evidence for substantially increased river flow and thus higher effective moisture compared with modern conditions. However, dating of the large meander features is uncertain, and they could be Pleistocene [36].

Several climate records are available from inland sites in Texas, but it is not clear how well these records represent coastal conditions. For example, Holocene pollen records from a series of bog deposits in east-central Texas [37, 38] show a continuous and gradual trend of declining tree pollen and increasing grass and herb pollen through the Holocene. This pollen trend indicates a progressive change to drier and warmer conditions. The modern Post Oak Savanna vegeta- tion in central Texas has been present for at least $3.0 \mathrm{ka}$. Variations in $\delta^{13} \mathrm{C}$ of organic carbon in alluvial deposits from central Texas [39] have also been used to infer changes in Holocene vegetation. Although the sampling density is low and the records are discontinuous, the available data indicate a trend towards warmer and drier climate from early to late Holocene, which is consistent with the bog pollen records.

In the western part of the northern Gulf Coast (Texas), the available records indicate that effective moisture in the later part of the Holocene was reduced compared to that in the early part of the Holocene, primarily due to a reduction in the summer monsoon [40]. The inferred effective moisture decrease in the later part of the Holocene in the western northern Gulf Coast is consistent with estimates of the evolution of the Holocene monsoon derived from marine records (see Poore et al. (2005) [23]), but contrasts with the trend toward higher effective moisture in the later part of the Holocene observed in the eastern part of the northern Gulf Coast. This difference in effective moisture trends illustrates the regional variability of climate along the northern Gulf Coast.

\section{Floods and Droughts}

A variety of studies provide evidence for past major flood and drought intervals during the Holocene that may have affected the Northern Gulf Coast. For example, studies based on tree rings, lake sediments, and geomorphic features indicate that several multidecadal- to centennial-length droughts occurred across the central United States during the last $2.0 \mathrm{ka}$ [41]. Multidecadal droughts during the $13^{\text {th }}$ and $16^{\text {th }}$ centuries were more severe and widespread than the "dust bowl" event of the 1930s, and at least four severe, century-scale megadroughts affected the Great Plains and western United States between 2.0 to $.8 \mathrm{ka}$ [41]. Also, severe drought occurred over a wide area of the mid-continent of North America between 4.2 and $4.1 \mathrm{ka}$ [42].

Direct evidence for past drought conditions along the northern Gulf Coast are sparse. However, sand dunes from several localities in coastal Texas and western Louisiana show evidence of one or more intervals of dune mobility over a several-hundred-year period centered at about $1.0 \mathrm{ka}$ [40]. The arid conditions, inferred by dune activity, are consistent with megadroughts identified in the central U.S. at about 1.1 and $.8 \mathrm{ka}$ [41]. Sand dunes in coastal southeastern Louisiana, coastal Alabama, and northwestern Florida were active at times during the early Holocene. Dates of dune activity in southeastern Louisiana are clustered the early Holocene (11 to $8 \mathrm{ka})$, whereas most dates on dune activity in coastal Alabama and northwest tern Florida are between 7 and $5 \mathrm{ka}$ [40]. The limited data indicate that prolonged droughts have occurred along the northern Gulf Coast throughout the Holocene.

Evidence for changes in flood frequency during the Holocene in the Mississippi drainage basin is provided by the distribution of overbank deposits in the upper Mississippi Valley (e.g., Knox (1985, 1993) [43, 44]). Large floods, compared to contemporary long-term average floods, occurred between 6 and $4.5 \mathrm{ka}$ and between 3 and $2 \mathrm{ka}$ [43]. However, little evidence for discerning changes in the frequency and magnitude of flood events during the Holocene is available directly from the northern Gulf Coast. There are 


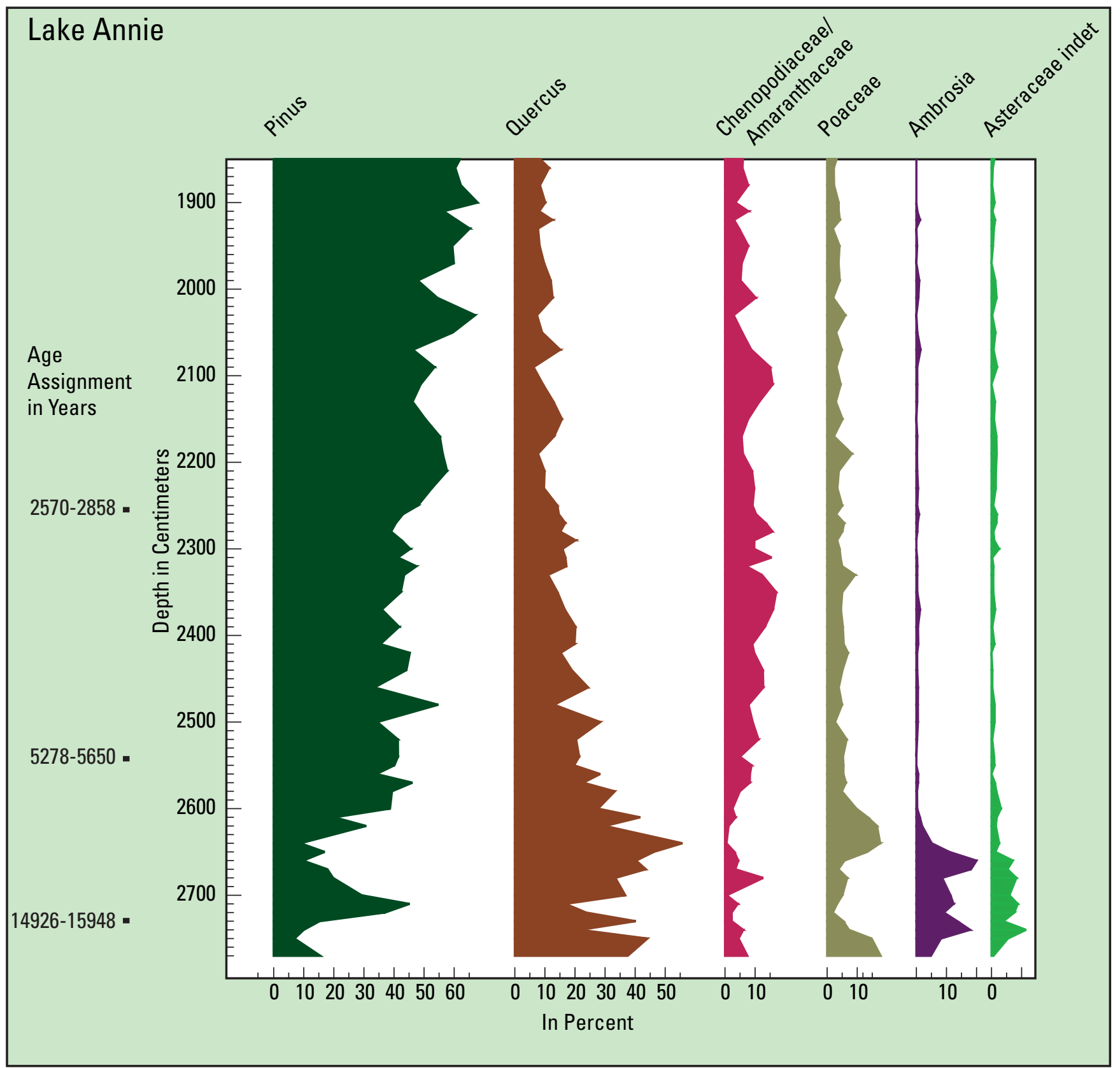

Fig. (6). Pollen record from Lake Annie, Florida (Fig. 4). Plot shows relative abundance of key pollen types. Age assignments shown to left of depth scale are from radiocarbon dates that have been calibrated to calendar years. Note shift from Quercus (oak) to Pinus (pine) domination of the pollen assemblage at about 5,000 years ago [30].

geomorphic features like the previously mentioned large fossil meander scars along the Sabine River in southwest Louisiana that indicate substantially increased river flow. However, uncertainty regarding the age of these large meander features [36] and other geomorphic features indicating increased river flow makes interpretation of the timing and duration of flood events problematic.

A different approach to developing information on past flood intervals along the northern Gulf Coast is to examine marine deposits on the continental shelf and slope for evidence of increased outflow of freshwater and terrestrial material into the Gulf of Mexico. Brown et al. (1999) [45] used faunal, isotopic, and grain-size variations in core EN 32-PC2 from the Orca Basin to develop a record of major Mississippi River flood events. The EN 32-PC2 record spans the last 5 ka with sample resolution that varies from a century to several decades. Brown et al. [45] identified seven major flood events that occurred every 1.2 and $.5 \mathrm{ka}$. However, data from EN 32-PC2 are difficult to interpret because they are noisy, and considerable variation is seen in the effects of individual flood events on the faunal, isotope, and grain size records.

Freshwater outflow to the GOM from rivers can influence the oxygen content of subsurface coastal waters. The development of low-oxygen bottom-water conditions off the Mississippi Delta is related to increased outflow of freshwater and nutrient loading from the Mississippi River [46]. The 
increased outflow of freshwater leads to density stratification of nearshore waters, which prevents mixing of the water column. The lack of mixing causes the oxygen in subsurface waters to be used up by decay of organic material that sinks from phytoplankton blooms in the surface waters. Osterman et al. (2008) [47] found evidence in a sediment core recovered near the Mississippi Delta for the periodic development of low-oxygen bottom-water conditions extending back for 1 $\mathrm{ka}$. Therefore, the periodic low-oxygen conditions prior to 1900 AD (Fig. 7) documented by Osterman et al. (2008) [47] likely represent Mississippi or Atchafalaya River flood events. The correlation of the low-oxygen bottom-water record shown in Fig. (7) with the climate of the northern Gulf
Coast is uncertain for two reasons. First, the northern GOM shelf is a dynamic environment and sediments can be remobilized and redeposited during storms (e.g., Swarzenski et al. (2007) [48]). Thus, assigning ages to the pre-1900 AD events shown on Fig. (7) is difficult because material suitable for ${ }^{14} \mathrm{C}$ dating was only found near the bottom of the core, and one cannot confidently assume a continuous accumulation rate to interpolate the age of the low-oxygen bottom-water events. Second, the Mississippi River drains a large area of the mid-continent, so it is not clear that a Mississippi River flood event necessarily means increased effective moisture along the northern Gulf Coast.

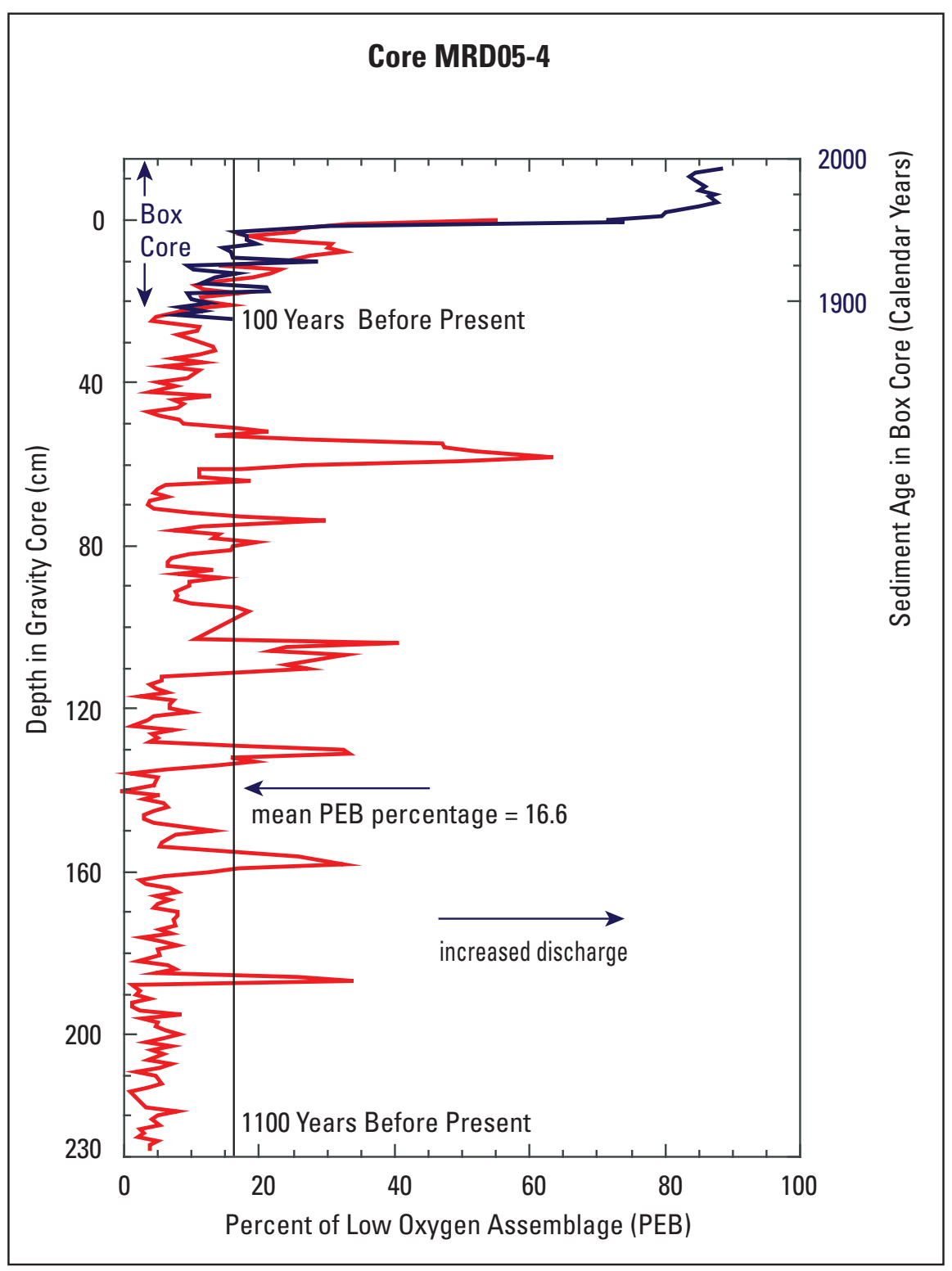

Fig. (7). Relative abundance variation of low-oxygen tolerant benthic foraminifers (= PEB) in core MRD05-4 from the Louisiana Shelf (Fig. 4). The record is a combination of data from a box core and gravity core from the same locality (see discussion in Osterman et al. (2008) [47]). Chronology for the upper part of the record is based on ${ }^{210} \mathrm{~Pb}$ measured in the box core. The single date indicated at $220 \mathrm{~cm}$ is based on two radiocarbon dates [47]. High PEB values in the top part of the record (last 50 years) represent development of hypoxia near the Mississippi River due to increased nutrient loading related to the use of fertilizer in the Mississippi River Basin. High values of PEB below $40 \mathrm{~cm}$ depth represent development of low-oxygen bottom water conditions that likely represent increased discharge from the Mississippi River of the Atchafalaya River and thus indicate past floods that transported more natural nutrients to the Louisiana Shelf. No dates are available above $240 \mathrm{~cm}$ in the gravity core so the timing of the individual "flood events" indicated by high PEB values cannot be estimated. 


\section{Storms}

Analyses of historical records indicate that the number of major hurricanes making landfall along the Gulf and Atlantic Coasts varies through time (see Fig. 4 and discussion in Goldenberg et al. (2001) [12]). The variability in hurricane activity has been linked to multidecadal cycles in SST in the Atlantic Ocean [14] and to atmospheric circulation changes associated with El Niño events [13]. Periodic decadal-long increases in SST in the equatorial and mid-latitude North Atlantic associated with the Atlantic Multidecadal Oscillation are thought to provide favorable conditions for forming hurricanes [14]. In contrast El Niño events increase wind shear above the Caribbean and Gulf of Mexico, which inhibits the formation of hurricanes. Thus increased occurrences of El Niño events are linked to intervals of fewer hurricanes [13]. However, the reliable historical record is relatively short, and longer records are needed to confidently identify cycles in hurricane activity and link these cycles to specific components of the climate system.

Studies of storm deposits in lagoons and coastal lakes (e.g., Liu 2004 [49]) provide one way to extend the record of hurricane activity back in time. These studies assume that sand layers in lagoons, coastal marshes, and coastal lakes that normally accumulate fine-grained sediments and organic matter are caused by major storms. Thus the distribution of sand layers through time in sediment cores is used as a proxy for storm activity, with the thickness and lateral extent of sand layers interpreted as a measure of storm intensity. The results can be difficult to interpret, because the impact of individual storms is geographically limited, and processes other than major storms can create sand layers in lagoons and coastal lakes.

Despite the potential difficulties in confidently identifying storm deposits, initial studies in the Gulf Coast region show promise. Records from Lake Shelby near Mobile Bay, Alabama and from Western Lake in the Florida Panhandle indicate that hurricane impacts were relatively high between 3.0 and 1.0 ka whereas hurricane activity was relatively low between 5.0 and 3.0 and during the last $1.0 \mathrm{ka}[50,51]$. Similar results were obtained from a study of hurricane-induced overwash deposits in a lagoon on the eastern margin of Puerto Rico [13]. However more work is needed to establish the variation of hurricane frequency in the Holocene and link that variation to specific forcing.

\section{Sea Level}

Evidence for sea-level history of the Gulf Coast, since the last glacial maximum, has been recently summarized and evaluated by Balsillie and Donoghue (2004) [52]. At the last glacial maximum (about $20 \mathrm{ka}$ ), sea level was about 120 meters lower than today. As the glaciers retreated from their maximum extent, sea level generally rose continuously but at varying rates into the Holocene. A brief reversal in sea-level rise associated with a major cooling event, known as the Younger Dryas [53], occurred just before the beginning of the Holocene [52]. At the start of the Holocene (about $10 \mathrm{ka}$ ) sea level was approximately 30 meters below modern sea level. Most reconstructions agree that between $10 \mathrm{ka}$ and 6 ka sea level rose to within a few meters of its present day position. The rise was fairly steady with minor oscillations. Interpretation of the Gulf Coast sea-level record for the last 6 $\mathrm{ka}$ is contentious. The traditional interpretation is that the rate of sea-level rise slowed at $6 \mathrm{ka}$ and then gradually increased asymptotically from 6 ka to the present (e.g., Otvos (2004) [54]). The alternative interpretation is that sea level approached modern level near $6 \mathrm{ka}$ and was higher than modern sea level several times during the last 6 ka (e.g., Blum et al. (2002) [55]).

The history of past sea level is often constructed by determining with respect to modern sea level the age and elevation of features that form very near sea level, such as basal peat deposits and beach ridges. Balsillie and Donoghue (2004) [52] investigated the northern Gulf Coast sea-level history of the youngest part of the Holocene by separating the features used to calibrate past sea level into two groups. One group consisted of features currently located seaward of the present shoreline, and the other group consisted of features currently located landward of the present shoreline. The sea-level histories derived from the two groups of calibration samples are very different (Fig. 8). Because of their loca-

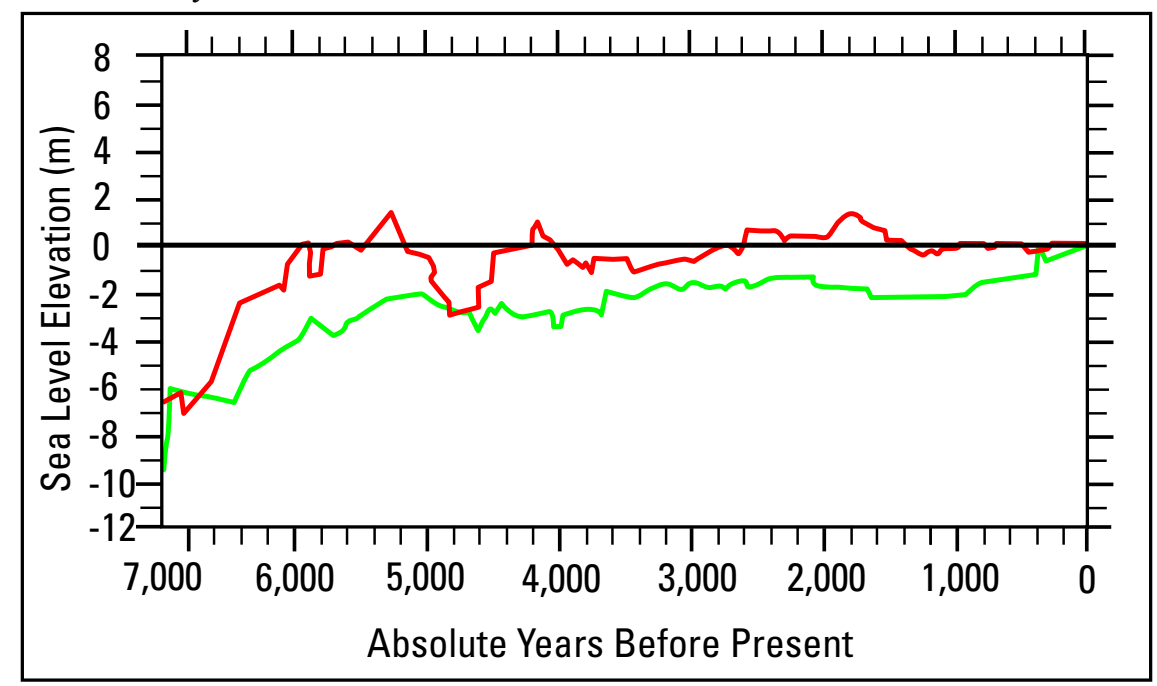

Fig. (8). Sea-level histories for northern Gulf of Mexico for the last 7,000 years developed from calibration samples currently located seaward of the present shoreline (green curve) and calibration samples that are currently located landward of the present shoreline (red curve). See text for discussion (modified from Balsillie and Donoghue (2004) [52]). 
tions, the offshore calibration features such as basal peat deposits cannot provide information about past shorelines that were higher than the modern shoreline. In contrast, features found landward of the modern shoreline such as beach ridges can and do provide evidence for sea level higher than today.

The evidence for sea level above modern levels compiled by Balsillie and Donoghue (2004) [52] (Fig. 8) for the northern Gulf Coast is convincing and is also consistent with Holocene eustatic sea-level reconstructions from other areas (e.g., Siddall et al. (2003) [56]). However, more work is needed in relatively stable areas of the northern Gulf Coast to establish the occurrence, timing, and duration of sea-level highstands during the last $6 \mathrm{ka}$.

\section{SUMMARY AND CONCLUSIONS}

Marine records from the northern GOM indicate that significant multidecadal- and century-scale variability was common during the Holocene. However, the number of records is limited. Additional highly resolved climate records from the northern GOM continental shelf and slope are needed to confirm the magnitude and patterns of variability observed in the Pigmy and Orca Basin SST records [27, 28] and to test the spatial coherence of such signals. For example, foraminifer $\mathrm{Mg} / \mathrm{Ca}$ SST estimates for the last $1.0 \mathrm{ka}$ developed from cores in the Florida Straits [57], differ significantly from the Pigmy Basin record.

Broad trends in Holocene climate and environmental change along the eastern portion of the Gulf Coast are evident from existing pollen records, but the overwhelming abundance of oak and pine pollen in most lake records tends to obscure details, and little work has been done to identify high-frequency changes. Continuous and well-dated records of climate and climate variability in the western portion of the Gulf Coast are essentially lacking. A network of records from coastal marshes and wetlands, which tend to provide information on local conditions [30], in conjunction with records from larger lakes and estuaries that integrate conditions on a regional scale is needed to reveal temporal and spatial patterns of climate change and variability across the Gulf Coast. Studies with sufficient age control and sampling density to resolve decadal- to multidecadal-scale features are needed to compare with and compliment offshore records. Long and continuous records from both marine and terrestrial environments are needed to test the link between solar output and multidecadal- to century-scale climate variability.

Information on Holocene flood and drought patterns and storm frequency in the Gulf Coast region is limited. Records of floods may be preserved in continental-shelf records but the dating and continuity of these records present challenges. Studies of past storm deposits show promise, but additional work is needed to evaluate techniques and develop regional patterns.

The recent summary of sea-level history of the northern Gulf Coast by Balsillie and Donoghue (2004) [52] presents convincing evidence that sea level was higher than modern sea level several times during the last few thousand years. However, additional records from relatively stable areas of the northern Gulf Coast are needed to establish the details of sea-level highstands during the latest part of the Holocene.

\section{ACKNOWLEDGEMENTS}

I thank Deb Willard and Lisa Osterman for discussions and constructive comments on a draft of this report. Constructive comments by John Brock and Barbara Lidz are also appreciated. Special thanks are due to Wendy Kelly, Marynia Kolak and Theresa Burress for help with resource material. I thank Laurinda Travers and Kathryn Smith for help with illustrations.

\section{REFERENCES}

[1] Lavoie D. Northern Gulf of Mexico: USGS science contributions to a resilient coast 2006-2011. Lacombe, LA: U.S. Geological Survey; 2007. Fact Sheet 2007-3075.

[2] Day JW, Jr., Barras J, Clairain E, et al. Implications of global climatic change and energy cost and availability for the restoration of the Mississippi delta. Ecol Eng 2005; 24(4): 253-65.

[3] Intergovernmental Panel on Climate Change (IPCC). Climate change 2007: impacts, adaptation and vulnerability: working Group II contribution to the fourth assessment report of the Intergovernmental Panel on Climate Change. Cambridge: Cambridge University Press, 2007.

[4] Wang C, Enfield DB. The tropical western hemisphere warm pool. Geophys Res Lett 2001; 28(8): 1635-8.

[5] Oglesby RJ, Maasch KA, Saltzman B. Glacial meltwater cooling of the Gulf of Mexico: GCM implications for Holocene and presentday climates. Clim Dyn 1989; 3(3): 115-33.

[6] Muller-Karger FE, Walsh JJ, Evans RH, Meyers MB. On the seasonal phytoplankton concentration and sea surface temperature cycles of the Gulf of Mexico as determined by satellites. J Geophys Res 1991; 96(C7): 12645-65.

[7] Brunner CA. Paleoceanography of surface waters in the Gulf of Mexico during the late quaternary. Quat Res 1982; 17(1): 105-19.

[8] Bailey RG. Ecoregions information. 1995 [cited August 2007]. Available from: http://www.fs.fed.us/rm/analytics/publications/ ecoregions_information.html

[9] Philander SG. In: Schneider SH, Ed, Encyclopedia of climate and weather. New York: Oxford University Press, 1996; 273-7.

[10] Darby R, Sondag R. Precipitation departures from normal along the northwest Gulf coast during several strong El Nino events. 2003 [cited August 2007]. Available from: http://www.srh.noaa.gov/lch/ research/bptlch.php

[11] Gray WM. Atlantic seasonal hurricane frequency. Part I: El Niño and $30 \mathrm{mb}$ quasi-biennial oscillation influences. Mon Weather Rev 1984; 112(9): 1649-68.

[12] Goldenberg SB, Landsea CW, Mestas-Nunez AM, Gray WM. The recent increase in Atlantic hurricane activity: causes and implications. Science 2001; 293(5529): 474-9.

[13] Donnelly JP, Woodruff JD. Intense hurricane activity over the past 5,000 years controlled by El Nino and the West African monsoon. Nature 2007; 447(7143): 465-8.

[14] Kerr RA. Atlantic climate pacemaker for millennia past, decades hence? Science 2005; 309(5731): 41-2.

[15] Enfield DB, Mestas-Nuñez AM, Trimble PJ. The Atlantic multidecadal oscillation and its relation to rainfall and river flows in the continental U.S. Geophys Res Lett 2001; 28(10): 2077-80.

[16] Malmgren B, Kennett JP. Principal component analysis of Quaternary planktic foraminifera in the Gulf of Mexico; paleoclimatic applications. Mar Micropaleontol 1976; 1(4): 299-306.

[17] Imbrie J, Kipp NG. In: Turekian KK, Ed, Late Cenozoic glacial ages. New Haven: Yale University Press, 1971; 71-181.

[18] Kennett JP, Elmstrom K, Penrose N. The last deglaciation in Orca Basin, Gulf of Mexico: high-resolution planktonic foraminiferal changes. Palaeogeogr Palaeoclimatol Palaeoecol 1985; 50(2-3): 189-216.

[19] Flower BP, Kennett JP. The Younger Dryas cool episode in the Gulf of Mexico. Paleoceanography 1990; 5: 949-61.

[20] Flower BP, Kennett JP, Stanley SM. In: Stanley SM, Ed. Effects of past global changes on life. Washington, DC: National Academy Press; 1995; 209-20.

[21] Poore RZ, Verardo S, Caplan J, Pavich K, Quinn T. In: Holmes C, Ed, Gulf of Mexico: its origins, waters, biota, and human impact. College Station: Texas A\&M University Press, in press. 
[22] Hodell DA, Curtis JH, Jones GA, et al. Reconstruction of Caribbean climate change over the past 10,500 years. Nature 1991; 352(6338): 790-3

[23] Poore RZ, Pavich MJ, Grissino-Mayer HD. Record of the North American southwest monsoon from Gulf of Mexico sediment cores. Geology 2005; 33(3): 209-12.

[24] Stuiver M, Braziunas TF. Sun, ocean, climate and atmospheric 14CO2: An evaluation of causal and spectral relationships. Holocene 1993; 3(4): 289-305.

[25] Hodell DA, Brenner M, Curtis JH, Guilderson T. Solar forcing of drought frequency in the Maya lowlands. Science 2001; 292(5520): 1367-70.

[26] Poore RZ, Quinn TM, Verardo S. Century-scale movement of the Atlantic Intertropical Convergence Zone linked to solar variability. Geophys Res Lett 2004; 31(12): L12214.

[27] LoDico JM, Flower BP, Quinn TM. Subcentennial-scale climatic and hydrologic variability in the Gulf of Mexico during the early Holocene. Paleoceanography 2006; 21(3): PA 3015.

[28] Richey JN, Poore RZ, Flower BP, Quinn TM. 1400 yr multiproxy record of climate variability from the northern Gulf of Mexico. Geology 2007; 35(5): 423-6.

[29] Eddy JA. Climate and the changing sun. Climatic Change 1977; 1(2): 173-90.

[30] Willard DA. In: Elias SA, Ed. Encyclopedia of Quaternary Science. 1st ed. Amsterdam: Elsevier; 2007; 2753-64.

[31] Watts WA. A late quaternary record of vegetation from lake annie, south-central Florida. Geology 1975; 3(6): 344-6.

[32] Watts WA, Hansen BCS. Pre-Holocene and Holocene pollen records of vegetation history from the Florida peninsula and their climatic implications. Palaeogeogr Palaeoclimatol Palaeoecol 1994; 109(2-4): 163-76

[33] Watts WA. Postglacial and interglacial vegetation history of southern Georgia and central Florida. Ecology 1971; 52(4): 676-90.

[34] Delcourt PA. Goshen Springs: late Quaternary vegetation record for southern Alabama. Ecology 1980; 61(2): 371-86.

[35] Fearn ML, Liu K. Maize pollen of 3500 BP from southern Alabama. Am Antiq 1995; 60: 109-17.

[36] Alford JJ, Holmes JC. Meander scars as evidence of major climate change in southwest Louisiana. Ann Assn Am Geog 1985; 75(3): 395-403.

[37] Larson DA, Bryant VM, Jr., Patty TS. Pollen analyses of a central Texas bog. Am Mid Nat 1972; 88: 358-67.

[38] Bryant VM, Jr. A 16,000 year pollen record of vegetational change in central Texas. Palynology 1977; 1: 143-56.

[39] Nordt LC, Boutton TW, Hallmark CT, Waters MR. Late Quaternary vegetation and climate changes in central Texas based on the isotopic composition of organic carbon. Quat Res 1994; 41(1): 10920.

[40] Otvos EG. Prospects for interregional correlations using Wisconsin and Holocene aridity episodes, northern Gulf of Mexico coastal plain. Quat Res 2004; 61(1): 105-18.

[41] Woodhouse CA, Overpeck JT. 2000 years of drought variability in the central United States. Bull Am Meteor Soc 1998; 79(12): 2693714 .
[42] Booth RK, Jackson ST, Forman SL, et al. A severe centennial-scale drought in mid-continental North America 4200 years ago and apparent global linkages. Holocene 2005; 15(3): 321-8.

[43] Knox JC. Responses of floods to Holocene climatic change in the Upper Mississippi Valley. Quat Res 1985; 23(3): 287-300.

[44] Knox JC. Large increases in flood magnitude in response to modest changes in climate. Nature 1993; 361(6411): 430-2.

[45] Brown P, Kennett JP, Ingram BL. Marine evidence for episodic Holocene megafloods in North America and the northern Gulf of Mexico. Paleoceanography 1999; 14(4): 498-510.

[46] Osterman LE, Poore RZ, Swarzenski PW, Turner RE. Reconstructing a $180 \mathrm{yr}$ record of natural and anthropogenic induced lowoxygen conditions from Louisiana continental shelf sediments. Geology $2005 ; 33(4): 329-32$

[47] Osterman LE, Poore RZ, Swarzenski PW. The last 1000 years of natural and anthropogenic low-oxygen bottom water on the Louisiana shelf, Gulf of Mexico. Mar Micropaleontol 2008; 66(3-4): 291303.

[48] Swarzenski PW, Campbell PL, Poore RZ, Osterman LE, Rosenbauer RJ. In: Farris GS, Smith G, Holm T, Robbins L, Demas C, Eds, Science and the storms: USGS response to the hurricanes of 2005, Circular 1306. Lafayette, LA: U.S. Geological Survey 2007; 197-200.

[49] Liu K-B. In: Murnane RJ, Liu K-B, Eds, Hurricanes and typhoons past, present, and future. New York: Columbia University Press, $2004 ; 13-57$

[50] Liu K-B, Fearn ML. Lake-sediment record of late Holocene hurricane activities from coastal Alabama. Geology 1993; 21(9): 793-6.

[51] Liu K-B, Fearn ML. Reconstruction of prehistoric landfall frequencies of catastrophic hurricanes in northwestern Florida from lake sediment records. Quat Res 2000; 54(2): 238-45.

[52] Balsillie JH, Donoghue JF. High resolution sea-level history for the Gulf of Mexico since the last glacial maximum: Florida Geological Survey; 2004. Report of Investigation 103.

[53] Fairbanks RG. A 17,000-year glacio-eustatic sea-level record influence of glacial melting rates on the Younger Dryas event and deep-ocean circulation. Nature 1989; 342(6250): 637-42.

[54] Otvos EG. Holocene gulf levels: Recognition issues and an updated sea-level curve. J Coastal Res 2004; 20(3): 680-99.

[55] Blum MD, Carter AE, Zayac T, Goble R. Middle Holocene sealevel and evolution of the Gulf of Mexico coast (USA). J Coasta Res 2002; SI36: 65-80

[56] Siddall M, Rohling EJ, Almogi-Labin A, et al. Sea-level fluctuations during the last glacial cycle. Nature 2003; 423(6942): 853-8.

[57] Lund DC, Curry W. Florida Current surface temperature and salinity variability during the last millennium. Paleoceanography 2006; 21(2): PA 2009.

[58] Brock JC, Barras J, Cahoon D, et al. Plan for the northern Gulf Coast ecosystem change and hazard susceptibility project. St. Petersburg, FL: U.S. Geological Survey, in press.

[59] National Oceanic and Atmospheric Administration (NOAA). Historical hurricane tracks [web site]. 2006 [cited February 2008]; Available from: http://maps.csc.noaa.gov/hurricanes/

(C) Richard Z. Poore; Licensee Bentham Open.

This is an open access article distributed under the terms of the Creative Commons Attribution License (http: //creativecommons.org/licenses/by/2.5/), which permits unrestrictive use, distribution, and reproduction in any medium, provided the original work is properly cited. 